\title{
Analysing Dialogue in STEM Classrooms in Ecuador: A Dual Socioeconomic Context in a High School
}

\author{
Lay-Wah Carolina Ching-Chiang $(\mathbb{a}$ and Juan Manuel Fernández-Cárdenas $(\mathbb{0}$ \\ Escuela de Humanidades y Educación, Tecnológico de Monterrey, Mexico
}

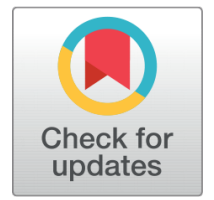

Received 2019-12-26

Revised 2020-01-30

Accepted 2020-04-10

Published 2020-07-15

\section{Corresponding Author}

Juan Manuel

Fernández-Cárdenas,

j.m.fernandez@tec.mx

Tecnológico de Monterrey Av. Eugenio Garza Sada 2501 Sur Aulas 2, Piso 464849 Monterrey, Nuevo León MÉXICO

DOI https://doi.org/10.7821/

naer.2020.7.529

Pages: 194-215

Distributed under

Creative Commons CC BY 4.0

Copyright: (C) The Author(s)

\section{ABSTRACT}

Science, Technology, Engineering and Maths education (STEM Education) is presented as a way to reduce marginalisation and promote inclusion in developing countries. This qualitative study aims to identify ways of reducing marginality and promoting inclusion through dialogic and transformative learning by high school teachers of the New Harvest School (NHS), particularly in STEM Education. Method: The study was carried out within the framework of the critical social approach identifying four characteristics of dialogism. The data comprised ethnographic observations of classes, and interviews with the selected teachers, the vice-chancellor and the administrator of the institution. Results: The dialogic characteristics of sequentiality, positioning, historicity and plurality were found in the science classes taught by the institution. Teachers have curricular knowledge capabilities regarding STEM education; however, recommendations were presented regarding the dialogic training that teachers should have, which made this study particularly relevant for improving teachers' skills in this field. This article suggests options to create spaces for the use of educational dialogue and a liberating practice of education.

\section{Keywords DIALOGUE, DIALOGIC LEARNING, SCIENCE EDUCATION, CLASSROOM INTERACTION, TEACHING PRACTICES}

\section{INTRODUCTION}

Globalisation, supported by the accelerated increase of innovations and technologies, has created complex scenarios worldwide modifying the way citizens cultivate their collective relationships in fundamental aspects such as culture, politics, ideologies and the environment. The economic gap generated by this process has concentrated wealth in a few hands, so that the majority of the population is now marginalised in their access to resources and opportunities for improvement (Montgomery \& Fernández-Cárdenas, 2018). That results in challenges, especially for developing countries trying to fight disparity. Studies from developed countries have proven a relationship between expenditure in scientific, technological, engineering and mathematical education (STEM) and economic growth (Hanushek

\section{OPEN ACCESS}


\& Woessmann, 2015). Thus, a strong relationship seemingly exists between educational quality and economic development (Asmolov, 2013).

In the case of Ecuador, as a developing country, some social and economic problems related to the lack of scientific and technological education make the country vulnerable in its efforts to sustain an economy which is not dependent on oil exports and other commodities. Moreover, international and national educational assessments for Ecuador do not show any encouraging results. In the PISA assessments, only $16 \%$ of 15 -year-olds in Ecuador reached PISA proficiency level 2 in reading scores, $43 \%$ did so in science, and $29 \%$ in mathematics (INEVAL, 2018a). These scores are particularly low among girls and underprivileged students in the Ser Bachiller test, a national exam that students should take for graduating at high school. The percentages of students scoring low in this test were situated at $35 \%$ in mathematics and $22.8 \%$ in science. Most students were placed in the elemental scoring -between 7 and 7.99 out of 10 (INEVAL, 2018b). In sum, these results highlight how hard social and economic mobility is for marginalised individuals within world economies.

This reality is not unknown to policy makers, entrepreneurs and the educational community. Joint efforts have been made to counter these results under the new STEM education paradigm. Ecuadorean schools are trying to develop ways to implement STEM education in their curricula, probably without fully understanding it. Far from being a contentbased learning, STEM education is an integrated curricular approach (Kelley \& Knowles, 2016) which could foster the development of abilities and lifelong learning skills (Pickering, Yuen, \& Wang, 2016). In that sense, it seems suitable for schools to consider three theories that influence the STEM education model: (1) the sociocultural paradigm; (2) dialogism; and (3) social innovation. Next, we describe the relationship of each paradigm as a foundation for STEM education.

Firstly, the sociocultural studies of mind theory, led by Lev Vygotsky, sees cognitive development as being the result of the appropriation of cultural tools afforded by the social interaction of individuals with society and their own experiences (Fernández, Wegerif, Mercer, \& Rojas-Drummond, 2015). This paradigm describes sociocultural learning with three elements - a) the influence of the cultural environment; b) semiotic mediation; and c) the Zone of Proximal Development (ZPD) - as elements that influence this process. The combination of various levels in the social context to which an individual is exposed becomes necessary to apply a STEM model, insofar as taking these aspects into consideration allows us to device a conscious instructional design able to support a relevant educational process.

Secondly, one of the interpretive aspects when it comes to applying the sociocultural paradigm is the use of dialogue, as informed by Mikhail Bakhtin's Russian school of through his studies on semiotics and novelisation (Bakhtin, 1981, 1984, 2010). The link between STEM education and dialogism can be identified by utilising four elements of Bakhtin's theory - sequentiality; positioning; plurality; and historicity - to build scientific knowledge (Fernández-Cárdenas, 2014).

Similarly, in the Latin American context, Paulo Freire analysed dialogue as the key element for a liberating and transformative education based on participants' action and reflec- 
tion as a catalyst for aiming a better quality of life without oppression (Freire, 2000, 2008). Exactly like in the sociocultural paradigm, we see the openness to use dialogue as a semiotic mediation that seeks understanding and helps construct knowledge, by which we mean moving away from an oppressive education, making sure that the space in which education is managed is open to criticism.

Freire's detractors accuse him of having failed to address the ways in which oppression intertwines with ethnicity, class or sexual orientation (Roberts, 2015). However, dialogue also allows reflection (Sedova, 2017). Reflection in this dialogic process can lead to reduce inequities regarding a variety of ethnicity issues. That is how dialogue in STEM education could also create awareness and empower individuals.

The third theory is the one which presents the capabilities approach as part of social innovation. Sen (1985) proposes through its capabilities approach to assess individual wellbeing beyond the volume of resources a person owns, additionally taking into account the ability to function and the freedom to choose how to live. In other words, we can see how the measurement of human well-being expands beyond national economic production factors. Under this approach, human beings' abilities are considered opportunities to choose and develop one kind of life or another (Carvajal-Muñoz, 2014; Castillo, 2016). Thus, from the perspective of social justice, STEM education must be inclusive, democratic and relevant.

STEM education's combination of sociocultural theory, dialogism and the capabilities approach translates into a transformative type of learning. It develops a critical consciousness that promotes a meaningful creation of the world relevant to the participants (Britz, Hoffmann, Ponelis, Zimmer, \& Lor, 2013; Fernández-Limón, Fernández-Cárdenas, \& Galindo, 2018; Reynaga-Peña et al., 2018). Moreover, this approach to learning works as a mechanism to reduce marginality, so that communities can benefit both financially and socially, thus managing their quantification of well-being and quality of life based on alternative methods such as the capability approach (Sherman, 2016).

Educational institutions usually have the responsibility for training, preparing and educating students in the broadest sense, i.e. providing them with the tools needed for the ever-changing situations of society and companies (Sierra-Gómez, 2013). The current competences required for the 21st century have generated changes in the current educational systems. However, the model of some schools is still obsolete and the figure of teachers as transmitters of knowledge must be re-evaluated for them to become a learning facilitator (Gisbert, González, \& Esteves, 2016; Khan, 2017), in accordance with constructivist theories.

Considering the previous background, it thus becomes relevant to investigate what is happening in STEM classrooms. Consequently, this study set itself the goal of analysing the relationship between dialogism and STEM education through the following research question: How could a dialogic and transformative approach to STEM education in the New Harvest School (NHS) strengthen their? teaching process? 


\section{METHOD}

Our twofold proposal in this paper is: (1) to explore how the change of educational paradigm could be faced by the STEM teachers at NHS through dialogic and transformative learning; and (2) to identify the current profile of STEM teachers, so that the administrative team can take it into consideration as part of their teaching professional development.

\subsection{Methodological approach}

This study was conducted with the support of a critical qualitative methodology that used ethnographic tools (Bloome \& Green, 2015; J. Green \& Bloome, 2004; J. L. Green, Castanheira, Skukauskaite, \& Hammond, 2015). This allowed the development of "emerging and convergent designs that are structured during the search process" (Cifuentes-Gil, 2011, p.15) emphasising social relationships over the numerical and predictive character of quantitative research studies (Creswell, 2012; Sampieri \& Torres, 2018).

The critical social approach aligned with the qualitative methodology so that findings could be built through a collective process based on discursive and community argumentation, where the proposal consisted in generating processes of reflection, empowerment and transformation (Cifuentes-Gil, 2011). Additionally, the participation was registered with the aim of "collecting information specifically to guide the future" (Quintero, 2017, p. 57) by means of dialogic tools. This process involved looking, thinking and acting, which was repeated when the students reflected on their processes (Stringer, 2007).

To apply the methodological approach described above, we recognised the importance of a researcher's ethical code and alignment with ethical research concepts (Sobočan, Bertotti, \& Strom-Gottfried, 2019; Valenzuela-González \& Flores-Fahara, 2014). Intellectual honesty, informed consent and transferability were achieved through forms of consent, names of participants remained anonymous, and proper reference to previous works was carried out.

\subsection{Participants}

The study developed from August to November 2018 at NHS - an educational institution located in Guayaquil, Ecuador. NHS provides educational services both in the morning and in the afternoon. The cost of tuition for morning shift parents is higher than for the afternoon shift ones, who have fewer economic resources.

Four high school teachers named A, B, C, and D were selected to participate in this study because of their proximity to students who find themselves in the process of transition towards the university, as a result of which those teachers' work strongly affects their students' decision to choose STEM careers. Table 1 presents relevant characteristics of the participants in this study.

Teachers $\mathrm{A}$ and $\mathrm{B}$ were teachers with no previous dialogic teaching experience, while teachers $\mathrm{C}$ and $\mathrm{D}$ had indirect experiences because they had received International Baccalaureate training which revolves around 3 key elements - - 'Theory of Knowledge'; 


\begin{tabular}{lllll}
\hline \multicolumn{2}{l}{ Table 1} & Participants in the study & & \\
Teacher & Subject & Bachelor's degree & Gender & Working Shift \\
\hline A & Maths & Electrical Engineer & $\mathrm{M}$ & Morning / Afternoon \\
B & Chemistry & Chemical Engineer & $\mathrm{M}$ & Morning / Afternoon \\
C & Biology & Biologist & $\mathrm{F}$ & Morning \\
D & Environmental & Electrical Engineer & $\mathrm{M}$ & Morning \\
& System & & & \\
\hline
\end{tabular}

'Extended Essay'; and 'Creativity, activity and service' - that call for critical, emotional and process reflection (International Baccalaureate, 2020).

Additionally, the academic vice-chancellor and the administrator of the institution were interviewed about academic planning, teacher training and the infrastructure to support STEM Education. They both have worked at NHS for 12 years incorporating institutional educational plans as well as national changes into the curriculum.

\subsection{Instruments}

Observations and semi-structured interviews were performed for data collection purposes as specified in Table 2.

Table 2 Tools to collect data

\begin{tabular}{|c|c|c|}
\hline Instrument & Applied to & Description \\
\hline $\begin{array}{l}\text { Class Observa- } \\
\text { tion }\end{array}$ & 4 teachers $(\mathrm{A}, \mathrm{B}, \mathrm{C}$ and $\mathrm{D})$ & Dialogical actions are identified based on sequentiality, positioning, plurality and historicity. \\
\hline Interview & 4 teachers $(\mathrm{A}, \mathrm{B}, \mathrm{C}$ and $\mathrm{D})$ & $\begin{array}{l}\text { It reflects on the class observation identifying strengths, opportunity areas, and teaching commit- } \\
\text { ments for improvement. }\end{array}$ \\
\hline Interview & Vice-principal & Open questions regarding how academic support is given for a dialogic STEM education. \\
\hline Interview & Manager & $\begin{array}{l}\text { Open questions regarding how the administrative part gives support for a dialogic STEM educa- } \\
\text { tion. }\end{array}$ \\
\hline
\end{tabular}

The semi-structured interviews for teachers had open-ended questions divided into three sections: professional experience; dialogic elements in their classes; and transcripts. In turn, the semi-structured interview with the academic vice-chancellor contained openended questions divided into two sections: professional experience; and dialogic elements in the school. Finally, a semi-structured interview with the administrator included a section for: her professional experience; up-to-date achievements of the school; and areas of exploration for the future.

\subsection{Procedures to obtain information}

First, the classes observed were chosen through a mutual availability agreement, so that each teacher was expected to present the best version of their teaching style. After the four observations, transcripts were made based on which we proceeded to meet each teacher to reflect on the lesson process and to compare perspectives reshaping fieldnotes and obtaining 
information with semi-structured interviews.

The semi-structured interviews with the academic vice-principal and the administrator of the institution were conducted through separate appointments.

\subsection{Data analysis strategy}

The communication competence approach (Hymes, 2005) served to categorise the transcripts into communicative situations, events and acts (see also Rojas-Drummond, Mazón, Fernández-Cárdenas \& Wegerif, 2006). A review of the transcripts was carried out to verify the presence or absence of the four features characterising dialogism, identifying examples where they occurred. The data were classified according to analytic domains, as well as classifying the themes that emerged from participants.

To confirm the reliability of class observation, teachers were asked about their perceptions of the transcripts where they had been involved, so that they could confirm instances of sequentiality, positioning, plurality and historicity. It also helped to review the field notes taken throughout the observations. The additional data from the four teachers' interviews - and those with the academic vice-chancellor, as well as with the administrative staffwere analysed creating codes to classify the themes that emerged around their STEM teacher profile.

\section{RESULTS}

\subsection{Context of lessons}

Table 3 lists 8 variables that describe the context in which the four lessons were given. The most relevant findings about this table were: (1) afternoon classes used the national curriculum while morning class students received the International Baccalaureate Organisation Diploma Programme; and (2) professor A and B's class themes required the use of mathematical operations while those of professor $\mathrm{C}$ and $\mathrm{D}$ did not.

Table 3 General description of the observed classes

\begin{tabular}{|c|c|c|c|c|}
\hline & Professor A & Professor B & Professor C & Professor D \\
\hline Subject & Maths & Chemistry & Biology & Environmental Systems \\
\hline Schedule & Afternoon & Afternoon & Morning & Morning \\
\hline Number of students & 15 & 25 & 9 & 5 \\
\hline Grade & 12 th & 12 th & 11 th & 12 th \\
\hline Curriculum & National Curriculum & National Curriculum & $\begin{array}{l}\text { International Baccalaurate } \\
\text { Organization Curriculum }\end{array}$ & $\begin{array}{l}\text { International Baccalaurate } \\
\text { Organization Curriculum }\end{array}$ \\
\hline Topic & Combinatorics & Hydrides & $\begin{array}{l}\text { Meselson and Stahl exper- } \\
\text { iment }\end{array}$ & $\begin{array}{l}\text { Human systems and the } \\
\text { use of resources }\end{array}$ \\
\hline Objective & $\begin{array}{l}\text { To strengthen combinato- } \\
\text { rial recognition }\end{array}$ & $\begin{array}{l}\text { To recognise chemical ele- } \\
\text { ments, their valences and } \\
\text { formulations }\end{array}$ & $\begin{array}{l}\text { To identify why DNA } \\
\text { replication takes place }\end{array}$ & $\begin{array}{l}\text { To find factors that impact } \\
\text { this phenomenon }\end{array}$ \\
\hline
\end{tabular}




\subsection{Communication Ethnography}

Three types of communicative events were recognised in all four lessons: Initial moment; development moment; and closing moment. These communicative events are linked to the school methodology for developing critical thinking through lesson teaching and structure.

Tables 4 and 5 provide examples of the communication ethnographic structure for teacher B and teacher D. The initial moment had an "activation of previous knowledge" in both, but they differ on how they did it. In the case of teacher B, the activation emphasis was placed on conceptual definitions of the students' previous knowledge, while teacher D's class presented a question that emphasised the opinion and individual experience of students. The same difference appeared in the next type of communicative event, corresponding to the development moment. Teacher B attempted to promote students' levels of remembering and understanding, according to Bloom's taxonomy (1984), whereas teacher D's lesson focused on the analysing and evaluating levels.

Table 4 Teacher B's communication ethnography

\section{Turn Number Type of Communicative Event}

1-34 Initial moment: Anticipation

35-144 Development moment: Building knowledge about Hydrides

145-152 Closing (moment)

\section{Communicative Act}

1. Activation of previous knowledge about metal hydrides: their formation, valences and nomenclature

2. Exemplification of the topic with a stannous hydride exercise

3. Exemplification of the topic with a potassium hydride exercise

4. Exemplification of the topic with a calcium hydride exercise

5. Exemplification of the topic with a rubidium hydride exercise

6. Exemplification of the topic with a cadmium hydride exercise

7. Exemplification of the topic with a sodium hydride exercise

8. Exemplification of the topic with a chromium hydride exercise

9. Exemplification of the topic with a scandia hydride exercise

10. Exemplification of the topic with a lithium hydride exercise

11. Exemplification of the topic with a vanadium hydride exercise

12. Exemplification of the topic with a cesium hydride exercise

13. Exemplification of the topic with a chromium hydride exercise

14. Ask students if they have any questions

15.Explaining simplification in the hydride

16.Explaining variation in chrome valences

The results of the communication ethnographic? structure for teacher A were similar to those obtained by teacher B, whereas teacher C's achievements resembled those of teacher D.

\subsection{Dialogism in lessons}

It was found that the construction of academic knowledge in the four lessons - the same as in all spheres of human activity - required dialogue, in this case between teachers and students. The results of observing these four lessons showed the relevance of Bakhtin's theoretical elements (sequentiality, positioning, plurality and historicity) to build scientific knowledge. Some examples for each of them are offered below. 


\begin{tabular}{|c|c|c|}
\hline Turn Number & Type of Communicative Even & Communicative Act \\
\hline $1-26$ & Initial moment: Anticipation & $\begin{array}{l}\text { 1.Establishing the topic of the class "Human systems and the use of resources" } \\
\text { 2. Activation of previous knowledge through a question about environmental problems } \\
\text { given human growth } \\
\text { 3.Presentation of photography in India }\end{array}$ \\
\hline $27-52$ & $\begin{array}{l}\text { Development Moment: Children } \\
\text { in Human Systems and the use of } \\
\text { resources }\end{array}$ & $\begin{array}{l}\text { 4. Identifying reasons for children's mortality rate } \\
\text { 5. Recognising culture as a factor that influences beliefs about caring for parents in the future } \\
\text { 6. Discussing whether children are an economic asset }\end{array}$ \\
\hline $53-76$ & $\begin{array}{l}\text { Development Moment: Gender in } \\
\text { Human Systems and the use of } \\
\text { resources }\end{array}$ & $\begin{array}{l}\text { 7.Establishing roles according to gender } \\
\text { 8. Discussing the use of resources according to gender }\end{array}$ \\
\hline $77-145$ & $\begin{array}{l}\text { Development Moment: Family } \\
\text { planning in human systems and } \\
\text { resource use }\end{array}$ & $\begin{array}{l}\text { 9. Discussing the use of contraceptives } \\
\text { 10. Discussing the number of children per family } \\
\text { 11.Identification of the Association for the Welfare of the Ecuadorian Family (Aprofe) } \\
\text { 12.Establishing the importance of family planning 13.Establishing the importance of family } \\
\text { businesses }\end{array}$ \\
\hline $146-156$ & Closing (moment) & $\begin{array}{l}\text { 14.Identifying how family resources are managed } \\
\text { 15.Personal example of the teacher in resource management } \\
\text { 16.Setting an exam for the next class }\end{array}$ \\
\hline
\end{tabular}

\subsubsection{Sequentiality}

A total of 174, 152, 96 and 156 turns, respectively, were exchanged in the lessons taught by teachers A, B, C and D. Table 6 shows that the percentages corresponding to teachers' and students' turns were roughly the same. However, class D students participated to a greater extent despite the fact that this class had the smallest number of students.

Table 6 Sequentiality percentage

\begin{tabular}{lll} 
& Teacher & Students \\
\hline Class A & $50 \%$ & $50 \%$ \\
Class B & $48.68 \%$ & $51.32 \%$ \\
Class C & $45.83 \%$ & $54.17 \%$ \\
Class D & $35.9 \%$ & $64.1 \%$ \\
\hline
\end{tabular}

Sequentiality was not only expressed in the number of turns taken but also on the extent to which participants could follow the conversation. In Figure 1, the excerpt portraits a communicative act where teacher A's purpose consisted in exemplifying the issue of permutations with the practical case of changing positions. Sequentiality was verified when any student was able to express their desire to return to their original sitting position. Teacher A gave his consent in turn 11, and the other students, despite saying nothing, gave their consent by moving to their original sitting positions too. Interestingly, the teacher formally named this exercise as a 'permutation' in turn 12.

Sequentiality was also supported using gestures. Figure 2 presents sequentiality through the search of agreements and including the use of gestural components. Teacher B used the eraser to point at what he wanted to erase by making the corresponding gesture. The 


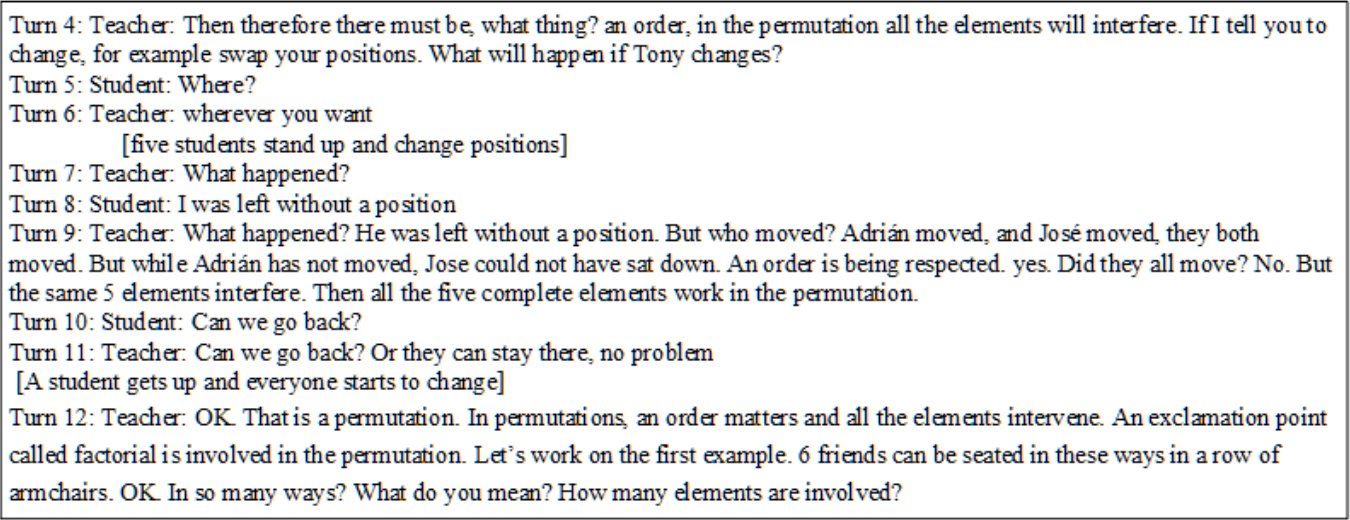

Figure 1 Excerpt example of sequentiality in teacher A's lesson

students' response determined his next action, which was erasing the whiteboard and projecting new exercises from the computer, in turn 35 .

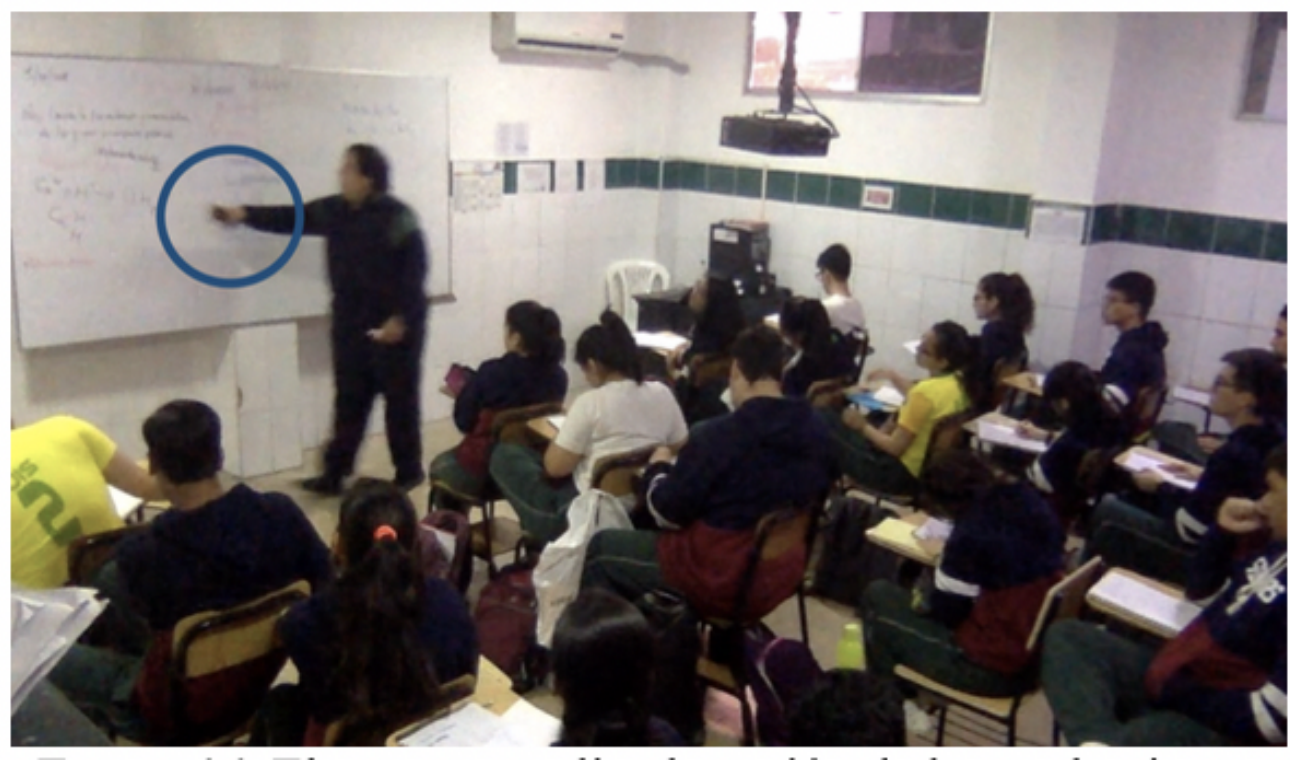

Figure 2 The teacher performs the action of erasing the board

Sequentiality was presented in different stages of communicative events using words that urged participants to become involved in dialogue. Table 7 collected words such as "what, how and why" that prompted participants to reflect upon the topic discussed and, in that way, accomplished the objective(s) of each lesson.

The use of those words to express sequentiality was portrayed in teacher C's lesson through the presentation of a video about the experiment carried out by Meselson and Stahl, after which she asked students questions about it. During that process, sequentiality was identified mainly by means of these words; for example, "what" was used 52 times, which 
Table 7 Use of words

How
What
When

How many

Why

Which

Questions

13

1

0

3

2

0

Teacher A

0

Teacher B

$\begin{array}{ll}7 & \\ 30 & \\ 0 & 52 \\ 7 & 0 \\ 4 & 0 \\ 7 & 2 \\ 7 & \end{array}$

\begin{tabular}{ll} 
Teacher C & Teacher D \\
\hline 10 & 16 \\
52 & 15 \\
0 & 4 \\
0 & 0 \\
2 & 6 \\
12 & 2 \\
0 & 0
\end{tabular}

prompted the recognition both of the self and of the other. In Figure 3 excerpt, teacher C's utilisation of these questions along with students' own reflection led themselves to set the purpose of this experiment, as in turn 7, when she asked "... What were they dealing with? What else were they looking for?". The students used terms such as prove, check, observe and combine, and in turn 12 teacher $\mathrm{C}$ reaffirmed the answers given by the students saying in her intervention "We have that scientists wanted to check, observe, compare..." By doing this, she recognised the different points of view and built up her next question based on them, when in the same turn she said, "So, what would be the conclusion".

\footnotetext{
Turn 3: Teacher: Ok guys, if we can see this experiment that worked because it is considered the most beautiful of biology, since it allowed me to? observe the DNA? Guys, what would the purpose of this experiment be?

Turn 4: Student 1: To prove that DNA has ... bone, to support the conservative test .

Turn 5: Teacher: very well, we can work on/with the semi-conservative DNA chain. What else? Mary

Turn 6: Student 2: Can we check if what is said really holds true for DNA, of replication?

Turn 7: Teacher: already, ap art from checking. What were they dealing with? What else were they looking for?

Turn 8: Student 1: To observe.

Turn 9: Student 3: To see the evolution of DNA structure over time because it said it first had only n14, only $15 \mathrm{n}$ the chain??

Turn 10: Student 2: Evolution

Turn 11: Student 3: and then they had combined after a generation. In another generation, he said that they had made a chain of n14

Turn 12: Teacher: We have that scientists wanted to check, observe, compare. So what would be the conclusion?
}

Figure 3 Excerpt Example of Sequentiality in teacher C's lesson

\subsubsection{Positioning}

Dialogism gives the opportunity for the actors taking part in the dialogic act to construct their own position with respect to others. This positioning was influenced by the construction of one's own posture and the contribution of knowledge made by the other parties. Table 8 shows the positioning by classifying the turns according to one of the six levels of thinking developed by Bloom (1984; see also Wei \& Ou, 2019). Most positionings were identified in lessons $\mathrm{A}, \mathrm{B}$ and $\mathrm{C}$, which focused more strongly on the remembering and understanding levels of thinking. In contrast, most of the positionings in lesson D emphasised the analysis and evaluation levels of thinking.

The positioning was described through the participation of students and the teacher with regard to the thinking levels of Bloom's taxonomy. For instance, Figure 4 portrays the 
Table 8 Positioning by level of thinking

\begin{tabular}{|c|c|c|c|c|c|c|c|c|}
\hline & $\begin{array}{l}\text { Class A: } \\
\text { Students }\end{array}$ & $\begin{array}{l}\text { Class A: } \\
\text { Teacher A }\end{array}$ & $\begin{array}{l}\text { Class B: Stu- } \\
\text { dents }\end{array}$ & $\begin{array}{l}\text { Class B: } \\
\text { Teacher B }\end{array}$ & $\begin{array}{l}\text { Class C: Stu- } \\
\text { dents }\end{array}$ & $\begin{array}{l}\text { Class C: } \\
\text { Teacher C }\end{array}$ & $\begin{array}{l}\text { Class D: Stu- } \\
\text { dents }\end{array}$ & $\begin{array}{l}\text { Class } \\
\text { Teacher D }\end{array}$ \\
\hline Remember & 22 & 16 & 35 & 35 & 18 & 20 & 10 & 18 \\
\hline Understand & 30 & 32 & 28 & 26 & 23 & 28 & 3 & 15 \\
\hline Apply & 25 & 21 & 5 & 11 & 3 & 4 & 4 & 12 \\
\hline Analyze & 9 & 17 & 6 & 6 & 0 & 0 & 24 & 37 \\
\hline Evaluate & 1 & 1 & 0 & 0 & 0 & 0 & 15 & 18 \\
\hline Create & 0 & 0 & 0 & 0 & 0 & 0 & 0 & 0 \\
\hline
\end{tabular}

conversation in Teachers D's class about children as an economic asset in Ecuador. This particular conversation was built upon the participants' beliefs about the economic reasons for a 10-year-old kid in an agricultural society to work, while other children might be studying elsewhere. In turn 53, the teacher opened the possibility to discuss the issue of gender role in agricultural societies, with the question "...how good is it to have a boy or a girl?," so that students were able to take a position. In turn 57, one student argued that there was sexism in the way roles were divided and voiced out that this was an area to work on, by saying "...because there are many things that women and men can do..." However, he recognised that there might be a difference between the beliefs of people from rural and urban areas.

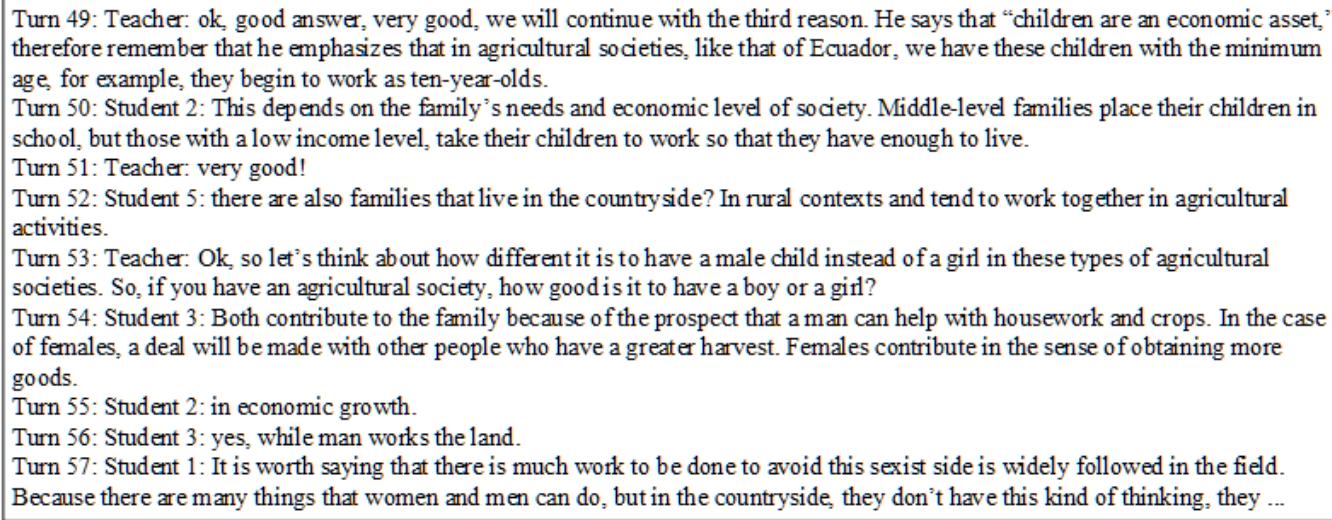

Figure 4 Excerpt Example of Positioning in teacher D's lesson

Figure 5 portrays one conversation in Teacher B's class which focused on strengthening the topic of metal hydrides through exercises on the board. In that lesson, as in class A and C, the interaction relied only on Bloom's level of recognition (1984); and therefore, dialogue did not work for the purpose of analysing, evaluating or creating - in contrast to class D. The positioning construction was led by the teacher, who posed questions that required the students' previous knowledge to support their dialogic position. In turn 106, the teacher made student 13 see how the solution to that exercise was actually not possible, because "you can realise that, in this case, it is poorly formulated"; this meant that he did not have to focus on solving it. However, in turn 110, the students laughed at student 13 because he was 
surprised to check that the exercise had such characteristics. It is worth highlighting that not all events required higher levels of cognition, and thus, elaborate positionings. However, we would suggest that this event was productive in highlighting the need for clearly formulated problems in order to make a solution possible.

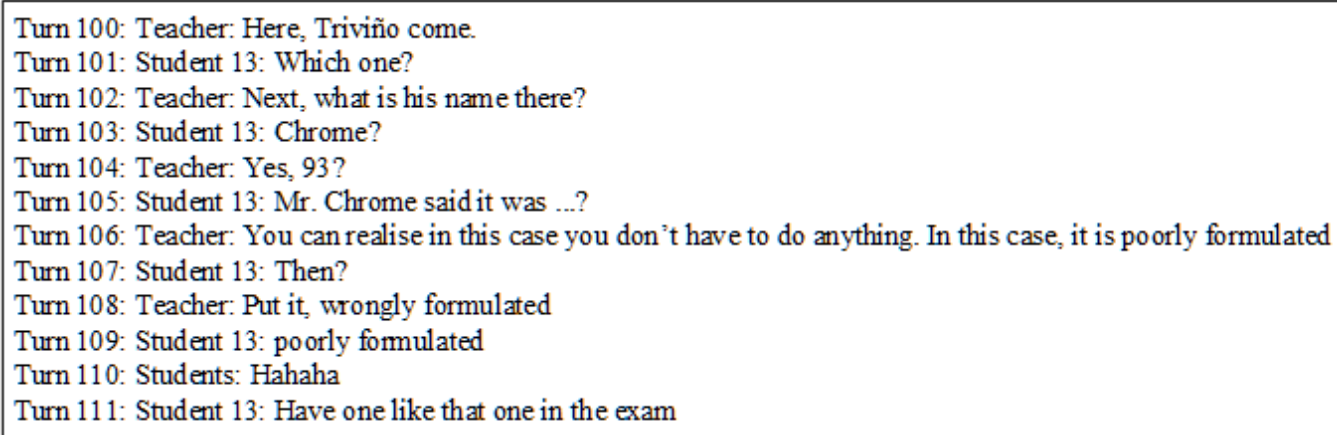

Figure 5 Excerpt Example of Positioning in teacher B's lesson

\subsubsection{Plurality}

The plurality of voices can be recognised in the participation of other voices when building dialogue. Figure 6 represents plurality in class D. In this communicative act, the voices of the teacher and the students were related to the topic of taking care of old people. In turn 33, a student mentioned that "it is the tradition to take care of elders because they took care of us." There was a contrasting voice in turn 37 where Student 1 expressed "but in the United States, or in northern countries, they have the culture of turning 18 and go leave alone". The same topic gave the opportunity to create the expectation about their future(s) as well as to hear their voices. In turn 38, the teacher asked the students "Would you take care of your parents even when they are old and you have your own families?" In turn 39, a student answered, "I have to give my parents what they gave me."

Note at this point that the voice of culture had its own position in dialogue. It seemed to shape the participants' beliefs, actions and identity (Bakhtin, 1981; Kumpulainen \& Rajala, 2017).

Figure 7 presents class D, where voice plurality was shown using a more personal conversation approach to the topic that even caused laughter. The topic was not presented as formally as in the other classes. The previous topic that they were discussing was related to the number of children who could be raised? in different countries; therefore, in turns 96 to 107 , students' voices were recognised because the conversation changed directions when one student asked the teacher "... will you have a child?." This became a breaking point, since the teacher not only answered "this year maybe", but continued giving the opportunity for other students to ask more questions about it and even to make jokes with questions like "for Christmas?." Dialogue implies that building a consensus is not necessary, but it could prove collectively useful to express a variety of positions as an aesthetic exercise providing 
Turn 30: Teacher: ok, very good Now, let's continue with the following topic, it says security at all ages, so how does security at all ages relate to this whole part of the culture?

Turn 31: Student 5: The tradition is one in which the child, while growing up, is cared for by his parents, but when his parents are ...

Turn 32: Teacher: older? very good

Turn 33: Student 5: if older, this is the tradition, but there are people who do not follow this part.

Turn 34: Teacher: Do you consider that ...?

Turn 35: Student 1: we stay with our parents until we can grow and stay

Turn 36: Student 4: It is as if firstly parents take care of us, and then we will take care of them.

Turn 37: Student 1: but in the United States, or in (the) northern countries, they have the cul ture of turning 18 and only grow.

Turn 38: Teacher: this is a question for all of you, do you have the opportunity to answer, are you based on your future? Or would you take care of your parents even when they are old and you have your own family? Ok, what do you think of Carla, Miguel, Belén, Christian and then Mikael?

Turn 39: Student 2: I think so because of what my culture gave me. I think I have to give back to my parents what they gave me. For that reason when I grow up and have the solvency to help them, I will take care of them.

Turn 40: Teacher: ok ok What's up with you?

Turn 41: Student 2: My goal when I grow up is to be independent but without leaving my mother. I will do my best for her.

Turn 42: Student 3: I'll take care of my mom. Now, my mom takes cares of me.

Turn 43: Teacher: So, your mom is showing you the best example. What's the matter with you?

Turn 44: Student 4: I want to do the same thing my mom did for me.

Turn 45: Student 5: I want too

Turn 46: Student 1: I will take care of my parents.

Turn 47: Teacher: So, is it something cultural? You all seem to want to take care of your parents. Do they do the same in other countries? Is it just culture or are there other factors that affect it?

Turn 48: Student 5 : because we spend more time with them

Turn 49: Teacher: ok, good answer, very good, we will continue with the third reason. He says that "children are an economic asset," therefore remember that he emphasizes that in agricultural societies, like that as in Ecuador, we have these children with the minimum age, for ex ample, they begin to work when they are ten years old.

Figure 6 Excerpt First Example of Plurality in teacher D’s lesson

valuable insights (Fernández-Cárdenas, 2014; Kumpulainen \& Rajala, 2017). Moreover, the teacher used this event to inform students about the different options linked to the topic of planning a family. Thus, in turn 109, he introduced the concept of contraceptives and family counselling.

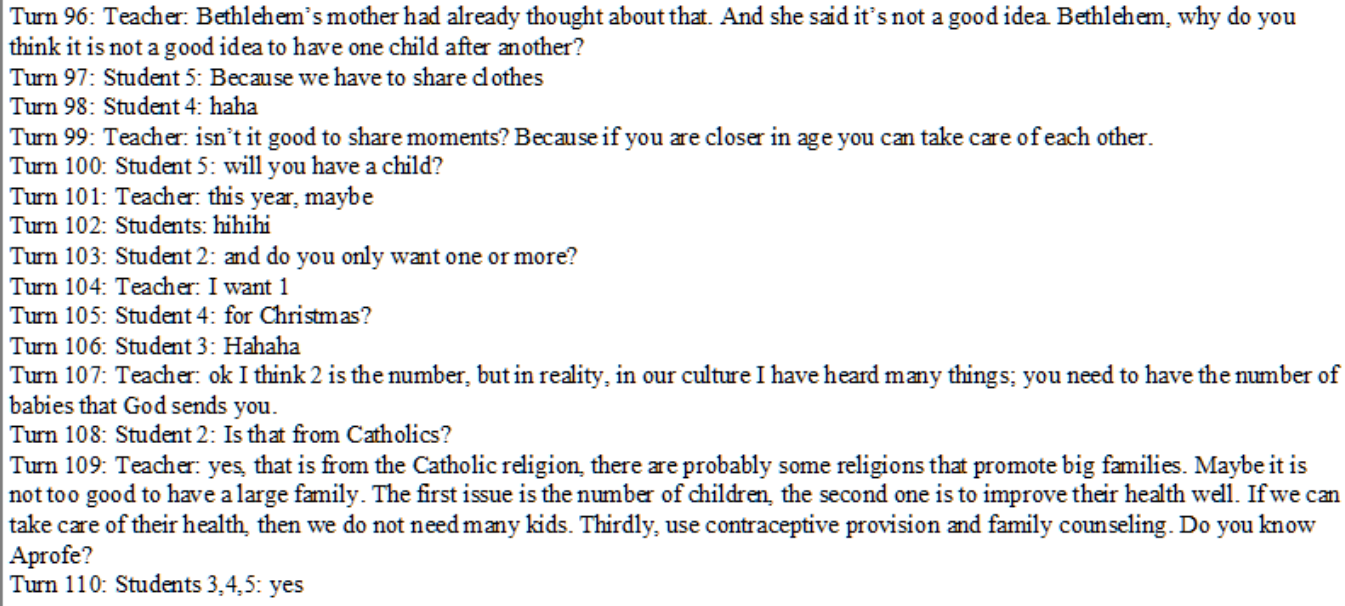

Figure 7 Excerpt Second Example of Plurality in teacher D’s lesson

The examples of the other classes lacked clear elements reflecting plurality. This probably had to do with the focus of classes on lower cognitive performance levels. In other words, lessons with a more procedural functioning provided a more basic argumentation where 
the requirement of plurality was not a component needed to have a productive interaction in those communicative events. On the opposite side, in lessons dealing with more controversial issues, such as lesson $\mathrm{D}$, the topic itself and the way in which the teacher handled the class gave more opportunities for students' cognition in order to go beyond the analysing level within the taxonomy developed by Bloom taxonomy (1956). That might explain why this class was rich in terms of plurality of voices and positionings.

\subsubsection{Historicity}

Historicity in dialogism manifests the discipline's own language, in this case of science,? to build conversations. Table 9 shows the use of scientific vocabulary and historicallydetermined disciplinary conversations in each class showing the number of times they were used in the lessons. For example, in Mathematics, the use of words such as permutation, factorial and elements; in Chemistry, the names of elements such as cadmium, vanadium or potassium; in Biology caesium, N15 and dense; and in Environmental Systems, the utilisation of resources, overcrowded and mortality. All these words represented the history of a discipline as part of a long conversation between scholars, but also between teachers and pupils referring to these words as cultural tools for naming academically phenomena both in the natural and in the social sphere (Fernández-Cárdenas, 2014; Maybin, 2006).

Table 9 Use of Scientific vocabulary in classes

\begin{tabular}{|c|c|c|c|c|c|c|c|}
\hline \multicolumn{2}{|c|}{ Teacher A - Mathematics } & \multicolumn{2}{|c|}{ Teacher B - Chemistry } & \multicolumn{2}{|c|}{ Teacher C - Biology } & \multicolumn{2}{|c|}{ Teacher D - Environmental } \\
\hline Vocabulary & Use & Vocabulary & Use & Vocabulary & Use & Vocabulary & Use \\
\hline Combinatorics & 1 & Cadmium & 1 & Addedin & 1 & Pollution & 1 \\
\hline Solution & 1 & Vanadium & 1 & Thymine & 1 & Maximum capacity & 1 \\
\hline Difference & 3 & Rubidium & 1 & Guanina & 1 & Energy consumption & 1 \\
\hline Exercises & 4 & Potassium & 1 & Cytosine & 1 & Disease & 1 \\
\hline Formula & 5 & Calcium & 1 & Genetics & 1 & Environment & 1 \\
\hline Number & 5 & Boron & 1 & Double & 1 & Increase & 2 \\
\hline Sum & 6 & Tin & 1 & RNA & 2 & Agricultural & 3 \\
\hline Process & 7 & Antimony & 1 & Test tube & 2 & Mortality & 3 \\
\hline Variation (s) & 8 & Sodium & 1 & $\begin{array}{l}\text { Delivery } \\
\text { courier }\end{array}$ & 2 & Overcrowded & 4 \\
\hline Simplify & 8 & Chrome & 1 & Helicase & 2 & Resources & 10 \\
\hline Permutation (s) & 14 & Scandium & 1 & Combination & 3 & & \\
\hline Factorial & 17 & Lithium & 1 & Dense & 4 & & \\
\hline \multirow[t]{2}{*}{ Elements } & 25 & Simplify & 2 & N15 & 5 & & \\
\hline & & Exercises & 2 & Cesium & 6 & & \\
\hline
\end{tabular}

For instance, in relation to the presence of historicity in a Biology class, Figure 8 shows that, seeking to construct knowledge in this lesson, the teacher resorted to students' previous knowledge. In turn 17, the student mentioned the type of bacteria as prokaryotes. In turn 19, the student answered the teacher with the name of two isotopes: N15 and N14. In turn 21 , a student highlighted that they had seen the periodic table last year. In turn 23 , the 
student referred to electrons, and in turn 25, to the location of neutrons that were in the core of the atoms. All the preceding examples supported the fact that participants remembered terminology specifically associated with the subject that they had learnt during the previous years.

Turn 16: Teacher: Changes. Perfect. Meselson and Stahl met in the summer of 1954, that is, the experiment was carried out specifically with the bacteria. And what are Natalie's bacteria?

Turn 17: Student 6: they are prokaryotes

Turn 18: Teacher: they are prokaryotic organisms. Within what is this great world of prokaryotes they began to work with the Echelichapolis bacteria. The Echelichapolis are found in an anaerobic environment, that is, they do not need oxygen to perform their metabolism. To be able to structure their DNA, these bacteria needed the presence of two isotopes.

Turn 19: Student 3: N15 and N14

Turn 20: Teacher: I have the isotopes n15 and n14. Linking with chemistry that is an isotope? ... Remember, we have it within the periodic table

Turn 21: Student 6: We saw it last year

Turn 22: Teacher: Nitrogen, right? Nitrogen can be changed. For nitrogen to become an isotope what do we need?

Turn 23: Student 3: Does it have to do anything with electrons?

Turn 24: Teacher: More than electrons, it has to do with neutron subatomic particles. So, for this chemical element to become an

isotope there has to be a change or variation ... of the neutrons. Where do I find the neutrons?

Turn 25: Student 6: In the core.

Turn 26: Teacher: In the nucleus of the atom. After they made a lot of vari ety and transformed nitrogen into radioactive isotope N14 and $\mathrm{N} 15$, they were able to do the experiment by growing bacteria in what is isotope N15, what did it say about that isotope?

Figure 8 Excerpt Example of Historicity in class C

Similarly, in relation to the role of historicity in a Mathematics class, Figure 9 presents the case of teacher A's lesson, where previous vocabulary related to the subject, such as the word "quinela" - a math-based game - was needed in order to construct knowledge. Starting precisely with the numbers which include their symbol and assigned meaning, e.g. numbers 8 and 2 in turn 105, and number 12 in turn 106. Within the same excerpt, in turn 108, the student recalls "I add them all" - which is historically associated with mathematical procedural knowledge.

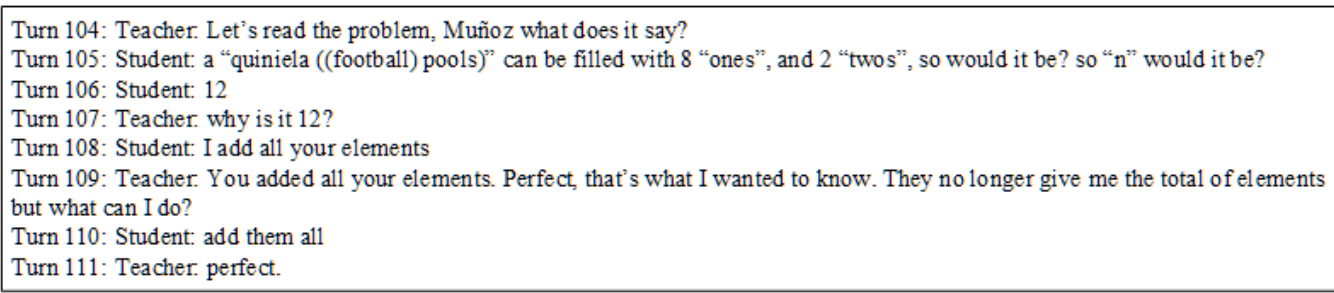

Figure 9 Excerpt Example of Historicity in class A

\subsection{Teacher profile}

Teachers' professional training levels in the school are varied. Out of 119 teachers, only $30 \%$ had a teaching career, while the other $70 \%$ had careers as Biologists, Electrical Engineers, Mechanical Engineers or experts in Business Administration, or they were studying. As mentioned above, the four teachers selected did not have a teaching career. Professor C, who is also a coordinator of the science area, mentioned that "[in the institution's science 
team] Many of us chose teaching for an economic reason in the beginning and then it became attractive as a profession. So, little by little we became teachers."

The knowledge society in the local context is directly influenced by the National Government through the Ministry of Education. According to the Vice-Chancellor: "Since the times of President Correa, the Unified General Baccalaureate system has been implemented as a measure for students to take a unified degree exam. This implies that all students now have taken the same subjects, which also led to reduce the hours of certain subjects so that everyone sees the same thing." This implied that science teachers had the worry about teaching the same content in less hours to prepare the students for the "Ser Bachiller test".

When teachers were asked about dialogism it was unknown to them. Teacher A replied: "Does it have to do with dialogue? I'm not sure", while teacher B gave a resonant "No." In turn, teacher C said "I did not know about dialogue. I could say that perhaps I practiced certain things as part of the use of constructivism, but just as I did as dialogism??". Finally, teacher D explained: "I agree, I didn't know either. Although there were certain things that helped me to do it thanks to the model of the International Baccalaureate, I did not know it nor its scope as a dialogue."

An analysis of teachers' pedagogical ideology revealed that their beliefs make them take certain actions which had consequences in their pedagogical development with a tendency to a liberating stance. For example, when they were asked about the positive aspects of classes, they stressed more active participation of students.

\section{DISCUSSION}

This study investigated how a dialogic and transformative training of baccalaureate teachers at NHS could strengthen their STEM teaching process. For this purpose, these teachers' classes were observed and recorded. In addition, they were interviewed at the end of the academic term. Field notes and transcripts from those classes, as well as interviews with teachers were analysed in terms of their possible dialogic traits. Similarly, the interviews proved helpful for contrasting the perspective of teachers with those of the vice-principal and the school manager. The results obtained from this research suggest that traits of dialogism can be found in the observed STEM classes.

Sequentiality, as part of the dialogic trait, showed that taking turns and shifting between them became an opportunity to manifest the recognition of both the "self" and the "other" as stated by Bakhtin (1981); or expressed differently, that there was a dialogue towards the construction of knowledge. In the cases of classes A, B and C, the turns were more or less equally divided between teachers and students, but in class D, students had $64 \%$ of turns, even though that was the class with fewer students. The previous findings could imply that teacher $\mathrm{D}$ gave more opportunities for students to have a voice, not only to answer but also to take the role of questioning and inquiring about the topics discussed.

However, the class topic itself might have been another variable that influenced dialogue. In teachers A and B's classes, tension existed between students to take turns through their participation, since it required being in front of their classmates to solve exercises on 
the board. In turn, teachers $\mathrm{C}$ and $\mathrm{D}$ preferred not to present mathematical calculations; instead, they chose to provide open topics, eliciting a more elaborate dialogue where students could see a context and create a sequence.

Another variable affecting sequentiality was the ability to lead students to exemplify what they proposed with meaningful life experiences. Despite the fact that the teacher in class A also used examples that illustrated real life experience, they did not necessarily connect with the students. For example, teacher A utilised the example of a casino to which students had not been, since they were prohibited in Ecuador some years ago. In contrast, teacher D took advantage of participants' families and even his family to build upon the topic.

Positioning was a feature that described dialogue and provided support in science education because it allowed building points of view that could be transformed while developing the dialogue in which other positions were recognised. Teachers had previously stated the objectives of their classes based on one of Bloom's levels of thinking (1984). Whereas Classes A, B and C had more turns in the lower levels of thinking, the dialogue in class D presented more turns corresponding to the higher level of thinking; i.e. class $\mathrm{D}$ was working on the critical consciousness of individuals, thus allowing them to take positions.

It also became clear that more questions were asked by teachers making students assume the role of suggesting answers. According to the scientific method premises, one should be able to ask questions; consequently, it would be beneficial to increase the rate of questions posed by students. Therefore, teachers arguably exhibited the Socratic method by using questions aimed at encouraging students to reflect and reason the answer through their own effort. However, a more dialogic exercise could have involved asking students to formulate the questions as well.

Plurality was based on the recognition of other voices that may have logic in what they want to convey. Especially in class $\mathrm{D}$, students were able to portray plurality in dialogue by recognising their local contexts, as well as opinions and practices from elsewhere, such as the United States and India. The teacher's role consisted in creating an "interactional space for students to talk and think together" (Kumpulainen \& Rajala, 2017).

Overall, teachers and students exhibited plurality in the form of freedom to think and talk to each other. That resulted in a liberating agenda through education, one in which students can empower themselves (Freire, 2000).

The use of academic vocabulary associated with the subjects as well as the analysis of fragments permitted to check that there was a historicity invoked by the participants. The construction of knowledge went from an everyday concept (something previously known to the individual) to one characterised by greater formality (see also Fernández-Limón, Fernández-Cárdenas, \& Gómez-Galindo, 2018). Figure 10 shows that each person has previously acquired (individual or shared) knowledge and a certain level of thinking about it. Knowledge can be developed thanks to these dialogic interactions. In this way, the feature of historicity evokes such knowledge and previous thinking levels of other individuals build on that new scientific knowledge.

For instance, communicative act 3 in teacher A's lesson - "exemplification of the subject of permutations with the exercise of changing positions"- showed how participants go from 


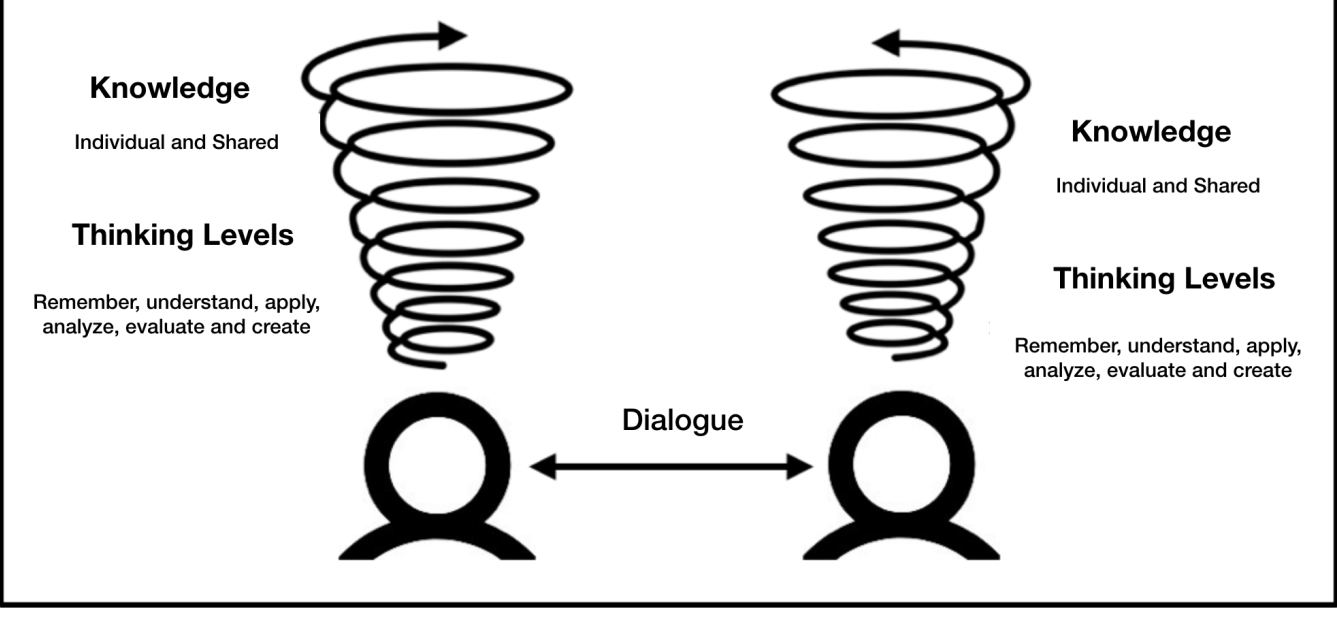

Figure 10 Knowledge creation spiral

talking about "changing positions," "elements," "order" and "interference of elements " to talking about "permutations." This determined the way in which the teacher worked building on students' previous knowledge in order to introduce the formal terminology of "permutations" and "factorial" at the end of this communicative act.

During the class observation process, teachers and students used gestural components to convey their position and prompted different turn sequences based on previous answers. The case of the teacher who made the gesture of erasing the board, or when he had to choose the student by pointing at him also became a dialogic element that strengthened communication.

The teachers' meta-conscious process guided the construction of knowledge for their classes as highlighted above. Even though they did not take teaching as a career, the dialogic position seemed to guarantee a construction of knowledge that allowed students to empower themselves. Teachers' knowledge building seemed to be affected by the type of curriculum. Teachers A and B were teaching the national curriculum, which focused on content, while teachers $C$ and D were teaching the International Baccalaureate Program centred on the core of emotional processes and knowledge reflection. This was also related to the economic differences regarding tuition between morning and afternoon shifts.

This research itself became a dialogic tool for presenting a dialogical education as a way to start innovative processes in the school. The interviews triggered a reflection process for the teachers, the vice principal and the school managers.

\section{CONCLUSIONS}

The aim of this research was to evaluate the ways in which the dialogic and transformative practices of high school teachers could strengthen STEM teaching approaches. It has 
been shown that the main benefit might lie in the fact that such as approach can provide opportunities to empower teachers and students' participation.

The doors to dialogue reshape the perception about the figure of the teacher's authority. This helps to build trust and create a suitable environment to promote learning centred on students and on supporting their development. Thus, it is important to build up a dialogic conversation between the institution and all the stakeholders related to it following Sedova (2017), according to whom dialogue is a dynamic and non-linear process.

This research managed to awaken a dialogue for the construction of scientific and technological knowledge between the teachers and authorities of the school where this study took place. The experience of creating the space to think together about the improvement of their learning experience brought out the intentions both of the participants and of the researcher to raise the educational quality of this institution.

As a result, dialogic training was proposed as a part of the innovations to strengthen the STEM teaching process for the students of this educational institution. A recommendation was made for the training sessions to be planned not only for the months during which the students do not attend school. Instead, they could be carried out throughout the year to follow up the processes transversely, revolving around dialogism to create a conversation where sequentiality, positioning, plurality and historicity are illustrated and discussed.

Limitations include the applicability of our findings to other contexts. Some characteristics of the Ecuadorian magisterium were inferred, but the findings only apply to NHS. Another constraint is the number of selected participants who responded to this survey, a trade-off for learning deeply about the few cases studied.

The results obtained for the four characteristics of dialogism have a variety of implications for further research efforts, namely: (1) the study of talk turn sequences during interaction; (2) the analysis of positionings; (3) the plurality of voices; and (4) the use of historically developed cultural tools and vocabulary in schools that have already set up a curriculum with a transversal axis in STEM. These elements could be used to analyse students' learning experience and to improve knowledge construction quality through the freedom they enjoy in such processes. A dialogic agenda can be suggested as a useful strategy to follow in the educational settings involved. This would also serve a higher ethical goal of developing more autonomous participants in STEM education, which can thus become more inclusive, democratic and relevant.

\section{REFERENCES}

Asmolov, A. G. (2013). Strategy and methodology for the sociocultural reform of education. Psychology in Russia, 6(1), 3-20. https://doi.org/10.11621/pir.2013.0101

Bakhtin, M. (1981). The dialogic imagination: Four essays. Austin: University of Texas Press. https:// doi.org/10.1075/z.184.15bak

Bakhtin, M. (1984). Problems of Dostoevsky's Poetics. Minneapolis: University of Minnesota Press. https://doi.org/10.5749/j.ctt22727z1

Bakhtin, M. (2010). Speech Genres and Other Late Essays. Texas: University of Texas Press. 
Bloom, B. S. (1984). Taxonomy of educational objectives. Vol. 1: Cognitive domain. Michigan: Longman.

Bloome, D., \& Green, J. (2015). The social and linguistic turns in studying language and literacy. In J. Rowsell \& K. Pahl (Eds.), The Routledge Handbook of Literacy Studies (pp. 20-30). Routledge.

Britz, J., Hoffmann, A., Ponelis, S., Zimmer, M., \& Lor, P. (2013). On considering the application of Amartya Sen's capability approach to an information-based rights framework. Information Development, 29(2), 106-113. https://doi.org/10.1177/0266666912454025

Carvajal-Muñoz, M. (2014). El enfoque de capacidad de Amartya Sen y sus limitaciones para la ciudadanía y la sociedad civil. Araucaria. Revista Iberoamericana de Filosofía, 16(31), 85103.

Castillo, M. (2016). Amartya Sen from social mirror of freedom. limits to individual capabilities approach. [Amartya Sen frente al espejo social de la libertad. Revista Internacional de Sociología, 74(3). https://doi.org/10.3989/ris.2016.74.3.038

Cifuentes-Gil, R. (2011). Diseño de proyectos de investigación cualitativa. Buenos Aires, Argentina: Noveduc.

Creswell, J. (2012). Educational research: Planning, conducting, and evaluating quantitative and qualitative research. Boston, MA: Prentice Hall.

Fernández, M., Wegerif, R., Mercer, N., \& Rojas-Drummond, S. (2015). Re-conceptualizing "scaffolding" and the zone of proximal development in the context of symmetrical collaborative learning. Journal of Classroom Interaction, 50(1), 54-72.

Fernández-Cárdenas, J. (2014). El dialogismo: Secuencialidad, posicionamiento, pluralidad e historicidad en el análisis de la práctica educativa. Sinéctica, 43, 183-203.

Fernández-Limón, C., Fernández-Cárdenas, J. M., \& Galindo, A. A. G. (2018). The role of nonformal contexts in teacher education for STEM: the case of horno3science and technology interactive centre. Journal of Education for Teaching, 44(1), 71-89. https://doi.org/10.1080/ 02607476.2018 .1422623

Freire, P. (2000). Pedagogy of the oppressed. London, United Kingdom: Bloomsbury Publishing. Freire, P. (2008). Paulo Freire: contribuciones para la pedagogía. Buenos Aires, Argentina: CLACSO.

Gisbert, M., González, J., \& Esteves, F. (2016). Competencia digital y competencia digital docente: una panorámica sobre el estado de la cuestión. Revista Interuniversitaria de Investigación en Tecnología Educativa, 0, 74-83. https://doi.org/10.6018/riite2016/257631

Green, J., \& Bloome, D. (2004). Ethnography and ethnographers of and in education: A situated perspective. In J. Flood, S. B. Heath, \& D. Lapp (Eds.), Handbook of research on teaching literacy through the communicative and visual arts (pp. 181-202). NY: MacMillan Publishers.

Green, J. L., Castanheira, M. L., Skukauskaite, A., \& Hammond, J. (2015). Developing a Multi-faceted Research Process: An Ethnographic Perspective for Reading Across Traditions. The Handbook of Classroom Discourse and Interaction, 115, 26-43. https://doi.org/10.1002/9781118531242 .ch2

Hanushek, E., \& Woessmann, L. (2015). The economic impact of educational quality. In P. Dixon, S. Humble, \& C. Counihan (Eds.), Handbook of International Development and Education (pp. 6-19). United Kingdom: Edward Elgar Publishing. https://doi.org/10.4337/9781783473540 .00009

Hymes, D. (2005). Models of the Interaction of Language and Social Life: Toward a Descriptive Theory. In S. F. Kiesling \& C. B. Paulston (Eds.), Intercultural Discourse and Communication: The Essential Readings. https://doi.org/10.1002/9780470758434.ch1

INEVAL. (2018a). Resultados de PISA para el desarrollo. Instituto Nacional de Evaluación Educativa. Retrieved from http://www.evaluacion.gob.ec/evaluaciones/pisa-documentacion/

INEVAL. (2018b). Resultados generales Ser Bachiller. Instituto Nacional de Evaluación Educa- 
tiva. Retrieved from http://www.evaluacion.gob.ec/evaluaciones/resultados-generales-ser -bachiller/

International Baccalaureate. (2020). DP curriculum | International Baccalaureate. Retrieved from https://www.ibo.org/programmes/diploma-programme/curriculum/

Kelley, T. R., \& Knowles, J. G. (2016). A conceptual framework for integrated STEM education. International Journal of STEM Education, 3(1), 11-11. https://doi.org/10.1186/s40594-016 $-0046-Z$

Khan, A. (2017). A Study of Narrative Teaching in Pakistani Universities in the Backdrop of Critical Pedagogy. Bulletin of Education and Research, 39(1).

Kumpulainen, K., \& Rajala, A. (2017). Dialogic teaching and students' discursive identity negotiation in the learning of science. Learning and Instruction, 48, 23-31. https://doi.org/10.1016/ j.learninstruc.2016.05.002

Maybin, J. (2006). Children's voices: Talk, knowledge and identity. New York: Palgrave Macmillan. https://doi.org/10.1057/9780230511958

Montgomery, C., \& Fernández-Cárdenas, J. M. (2018). Teaching STEM education through dialogue and transformative learning: global significance and local interactions in Mexico and the UK. Journal of Education for Teaching, 44(1), 2-13. https://doi.org/10.1080/02607476 .2018 .1422606

Pickering, T., Yuen, T., \& Wang, T. (2016). STEM conversations in social media: Implications on STEM education. 2016 IEEE International Conference on Teaching, Assessment, and Learning for Engineering (TALE) (pp. 296-302). https://doi.org/10.1109/TALE.2016.7851810

Quintero, E. (2017). Estrategias para investigar la innovación educativa. In M. S. Ramírez-Montoya \& J. R. Valenzuela-González (Eds.), Innovación Educativa. Investigación, formación, vinculación y visibilidad (pp. 53-70). Madrid: Síntesis.

Reynaga-Peña, C. G., Sandoval-Ríos, M., Torres-Frías, J., López-Suero, C., Garza, A. L., Félix, M. D., ... Ibanez, J. G. (2018). Creating a dialogic environment for transformative science teaching practices: towards an inclusive education for science. Journal of Education for Teaching, 44(1), 44-57. https://doi.org/10.1080/02607476.2018.1422620

Roberts, P. (2015). Paulo Freire and utopian education. Review of Education, Pedagogy, and Cultural Studies, 37(5), 376-392. https://doi.org/10.1080/10714413.2015.1091256

Rojas-Drummond, S., Mazón, N., Fernández, M., \& Wegerif, R. (2006). Explicit reasoning, creativity and co-construction in primary school children's collaborative activities. Thinking Skills and Creativity, 1(2), 84-94. https://doi.org/10.1016/j.tsc.2006.06.001

Sampieri, R. H., \& Torres, C. P. M. (2018). Metodología de la Investigación: Las Rutas Cuantitativa, Cualitativa y Mixta (and others, Ed.). México: McGraw Hill.

Sedova, K. (2017). A case study of a transition to dialogic teaching as a process of gradual change. Teaching and Teacher Education, 67, 278-290. https://doi.org/10.1016/j.tate.2017.06.018

Sen, A. (1985). Commodities and capabilities. Amsterdam: Elsevier Science.

Sherman, P. D. (2016). Value creating education and the capability approach: A comparative analysis of Soka education's facility to promote well-being and social justice. Cogent Education, 3(1). https://doi.org/10.1080/2331186X.2016.1138575

Sierra-Gómez, H. (2013). Aprendizaje activo como mejora de las actitudes de los estudiantes hacia el aprendizaje. España: Universidad Pública de Navarra.

Sobočan, A. M., Bertotti, T., \& Strom-Gottfried, K. (2019). Considerazioni etiche nella ricerca di servizio sociale. European Journal of Social Work, 22(5), 805-818. https://doi.org/10.1080/ 13691457.2018.1544117

Stringer, E. (2007). Action research. California: Sage Publications.

Valenzuela-González, R., \& Flores-Fahara, M. (2014). Fundamentos de investigación educativa. 2 y 
3 (Spanish Edition). In and others (Ed.), . Kindle Edition.

Wei, B., \& Ou, Y. (2019). A Comparative Analysis of Junior High School Science Curriculum Standards in Mainland China, Taiwan, Hong Kong, and Macao: Based on Revised Bloom's Taxonomy. International Journal of Science and Mathematics Education, 17(8), 1459-1474. https://doi.org/10.1007/s10763-018-9935-6 